\begin{tabular}{lll}
\hline Jurnal Teknologi Kimia Unimal & $\begin{array}{l}\text { Jurnal } \\
\text { Teknologi } \\
\text { Kimia } \\
\text { Unimal }\end{array}$ \\
\hline
\end{tabular}

\title{
PENGARUH SUHU DAN WAKTU REAKSI PADA PEMBUATAN KITOSAN DARI TULANG SOTONG (Sepia officinalis)
}

\author{
Etty Centaury Siregar ${ }^{1}$, Suryati ${ }^{1}$, Lukman Hakim $^{1}$ \\ Jurusan Teknik Kimia, Fakultas Teknik, Universitas Malikussaleh, \\ Laboratorium Teknik Kimia, J1. Batam No. 02, Bukit Indah, \\ Lhokseumawe 24353 \\ e-mail: ettycentaurysiregar@gmail.com
}

\begin{abstract}
Abstrak
Dilakukan penelitian pembuatan kitosan dengan menggunakan bahan baku tulang sotong. Kitosan dibuat dengan tiga tahapan, yaitu deproteinasi dengan mereaksikan bahan baku dengan $\mathrm{NaOH} 4 \%$, demineralisasi dengan menambahkan $\mathrm{HCl} 1 \mathrm{M}$, dan deasetilasi dengan mereaksikan hasil demineralisasi dengan $\mathrm{NaOH} 50 \%$ dengan variasi suhu dan waktu deasetilasi. Produk kitosan yang dihasilkan kemudian diuji kadar air, kadar abu, viskositas dan dikarakterisasi gugus fungsinya menggunakan spektrofotometer FT-IR. Hasil penelitian menunjukkan bahwa suhu berpengaruh pada kadar air, kadar abu dan viskositas kitosan. Waktu berpengaruh pada kadar abu kitosan. Derajat deasetilasi yang didapat pada penelitian ini sebesar 81,0231\%. Berdasarkan hasil FT-IR, kitosan yang dihasilkan dari tulang sotong pada penelitian ini memiliki gugus hidroksil, gugus amida, dan gugus amina yang merupakan ciri terbentuknya kitosan.
\end{abstract}

Kata kunci: kitosan, tulang sotong, suhu, waktu, deasetilasi

\section{PENDAHULUAN}

Kitin merupakan bahan organik utama terdapat pada kelompok hewan crustacea, insekta, fungi, mollusca dan arthropoda. Cangkang kepiting, udang dan lobster telah lama diketahui sebagai sumber bahan dasar produksi kitin, karena kandungan kitinnya cukup tinggi. Cangkang kering arthropoda rata-rata mengandung 20-50\% kitin (Suhardi, 1993).

Kitin yang telah dihilangkan gugus asetilnya melalui proses deasetilasi disebut kitosan. Kitosan (2-asetamida-deoksi- -D-glukosa) memiliki gugus amina 
bebas yang membuat polimer ini bersifat polikationik, sehingga polimer ini potensial untuk diaplikasikan dalam pengolahan limbah, obat-obatan, pengolahan makanan dan bioteknologi (Savant dkk., 2000).

Kitosan merupakan padatan amorf berwarna putih dengan struktur kristal tetap dari bentuk awal kitin murni, memiliki sifat biologi dan mekanik yang tinggi diantaranya adalah biorenewable, biodegradable, dan biofungsional. Kitosan mempunyai rantai yang lebih pendek daripada rantai kitin (Suhardi, 1993).

Salah satu komoditas perikanan Indonesia yang berorientasi ekspor adalah sotong. Pada umumnya sotong dimanfaatkan tanpa kepala atau tanpa kepala dan tulang bagian dalam. Hal itu menyebabkan limbah yang berasal dari sotong juga bervariasi berkisar antara 65- $85 \%$ dari berat sotong, tergantung dari jenisnya. Limbah sotong padat biasanya dimanfaatkan sebagai campuran pakan ternak dan sebagian lagi belum dimanfaatkan (Wiles, 2000).

Limbah padat molusca ini merupakan salah satu masalah yang harus dihadapi oleh pabrik pengolahan. Selama ini limbah tersebut dikeringkan dan dimanfaatkan sebagai pakan dan pupuk dengan nilai ekonomi yang rendah. Seiring dengan semakin majunya ilmu pengetahuan kini limbah sotong dapat dijadikan bahan untuk membuat kitin dan kitosan (Muzarelli, 1977).

\section{TINJAUAN PUSTAKA}

Kitosan dengan rumus molekul $\left(\mathrm{C}_{6} \mathrm{H}_{11} \mathrm{NO}_{4}\right)_{\mathrm{n}}$ adalah hasil hidrolisis kimiawi maupun enzimatik dari senyawa kitin. Kitosan merupakan kitin yang telah dihilangkan gugus asetilnya melalui proses deasetilasi. Jadi kitosan adalah suatu senyawa polimer dari glukosamin pada ikatan 11-1-4 atau 2-amino-2deoksi-D-glukosa (Alistair, 1995). Suatu molekul dikatakan kitin bila mempunyai derajat deasetilasi (DD) sampai 10\% dan kandungan nirogennya kurang dari $7 \%$. Dan dikatakan kitosan bila nitrogen yang terkandung pada molekulnya lebih besar dari 7\% berat dan derajad deasetilasi (DD) lebih dari 70\% (Muzzarelli,1985).

Kitosan dengan rumus molekul $\left(\mathrm{C}_{6} \mathrm{H}_{11} \mathrm{NO}_{4}\right)_{\mathrm{n}}$ adalah hasil hidrolisis kimiawi maupun enzimatik dari senyawa kitin. Kitosan merupakan kitin yang telah dihilangkan gugus asetilnya melalui proses deasetilasi. Jadi kitosan adalah suatu senyawa polimer dari glukosamin pada ikatan 11-1-4 atau 2-amino-2-

Makalah sudah dipresentasikan dalam Seminar Nasional Teknik Kimia 38 UNIMAL 2016 (17 Oktober 2016) 
deoksi-D-glukosa (Alistair, 1995). Suatu molekul dikatakan kitin bila mempunyai derajat deasetilasi (DD) sampai 10\% dan kandungan nirogennya kurang dari $7 \%$. Dan dikatakan kitosan bila nitrogen yang terkandung pada molekulnya lebih besar dari 7\% berat dan derajad deasetilasi (DD) lebih dari 70\% (Muzzarelli,1985).

Proses utama dalam pembuatan kitosan, meliputi penghilangan protein dan kandungan mineral melalui proses deproteinasi dan demineralisasi, yang masingmasing dilakukan dengan menggunakan larutan basa dan asam. Selanjutnya, kitosan diperoleh melalui proses deasetilasi dengan cara memanaskan dalam larutan basa (Tolaimatea et al., 2003).

Laju reaksi pada proses deasetilasi dipengaruhi oleh konsentrasi basa, temperatur, waktu reaksi, perbandingan antara kitin dengan larutan alkali, ukuran partikel. Pada konsentrasi $\mathrm{NaOH}$ tinggi. semakin banyak gugus asetil yang terlepas dari kitin sehingga meningkatkan derajat deasetilasi kitosan yang dihasilkan, Pada temperatur rendah reaksi akan berjalan lambat, sedangkan jika temperatur terlalu tinggi dapat merusak struktur bahan dasar (Suhardi, 1993).

\section{METODE PENELITIAN}

\subsection{Bahan}

Bahan-bahan yang digunakan pada penelitian ini adalah Tulang rawan sotong, Natrium hidroksida $(\mathrm{NaOH})$, Asam klorida $(\mathrm{HCl})$, Asam asetat, dan Aquades.

\subsection{Prosedur Kerja}

Tulang sotong dikeringkan kemudian dihaluskan. Selanjutnya dilakukan proses deproteinasi dengan menggunakan $\mathrm{NaOH} 4 \%$ pada suhu $80^{\circ} \mathrm{C}$ sambil dilakukan pengadukan, proses demineralisasi dengan menambahkan $\mathrm{HCl} 1 \mathrm{M}$ dengan perbandingan 1:15 (b/v) selama 120 menit pada suhu kamar. Proses deasetilasi dilakukan dengan mereaksikan hasil demineralisasi dengan $\mathrm{NaOH}$ $50 \%$ dengan perbandingan $1: 10(\mathrm{~b} / \mathrm{v})$ dengan variasi suhu $70,80,90,100^{\circ} \mathrm{C}$ selama 40, 50, 60, 70 menit, Hasil deasetilasi kemudian dicuci hingga $\mathrm{pH}$ netral dan dikeringkan. Kitosan yang diperoleh ditimbang dan dikarakterisasi kadar air, kadar abu viscositas dan gugus fungsinya. 


\section{HASIL DAN DISKUSI}

\subsection{Pembuatan Kitosan}

Proses pembuatan kitosan diawali dengan deproteinasi menggunakan $\mathrm{NaOH}$ 4\%. Proses deproteinasi, bertujuan untuk memutuskan ikatan antara protein dengan kitin. Deproteinasi dilakukan selama 60 menit dengan suhu $80^{\circ} \mathrm{C}$ dan perbandingan 1:10 b/v. Rendemen hasil deproteinasi yang didapatkan sebesar $92,1875 \%$.

Proses demineralisasi untuk menghilangkan mineral-mineral yang terdapat dalam bahan baku. Proses demineralisasi dilakukan dengan mereaksikan bahan baku dengan $\mathrm{HCl} 1 \mathrm{M}$ selama 120 menit pada suhu kamar. Rendemen hasil proses demineralisasi sebesar $87.85 \%$ berupa kitin.

Proses deasetilasi merupakan penghilangan gugus asetil kitin menjadi gugus amida kitosan. Proses deasetilasi kitin pada penelitian ini dilakukan dengan penambahan $\mathrm{NaOH} 50 \%$ dengan perbandingan $1: 10 \mathrm{~b} / \mathrm{v}$ dengan variasi konsentrasi dan suhu. Rata-rata rendemen pada proses deasetilasi adalah $75,775 \%$.

\subsection{Pengaruh Suhu dan Waktu Deasetilasi Terhadap Kadar Air Kitosan}

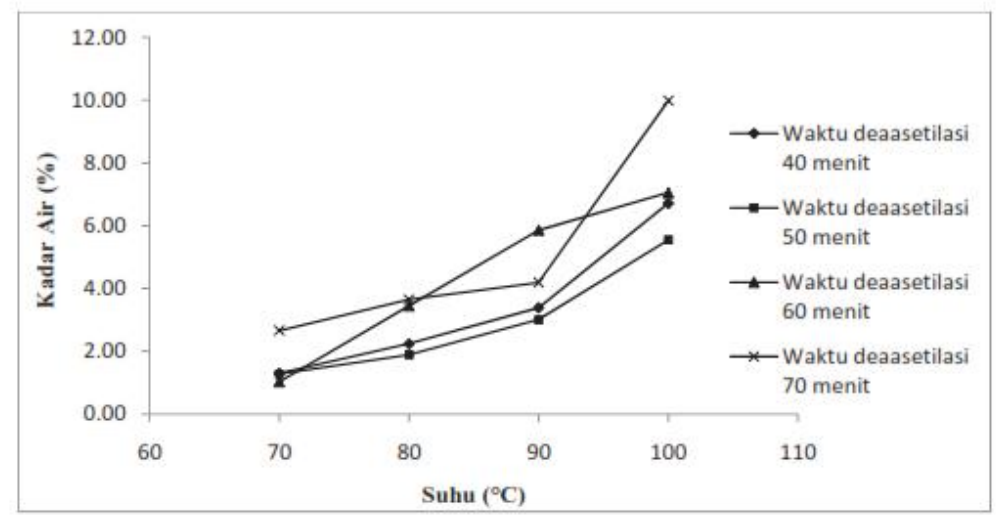

Gambar 4.1 Grafik hubungan antara suhu dan waktu deasetilasi terhadap kadar air kitosan

Pada grafik di atas dapat dilihat bahwa semakin tinggi suhu deasetilasi kitosan maka semakin tinggi pula kadar air yang didapat. Waktu deasetilasi juga mempengaruhi nilai dari kadar air kitosan. Sampel kitosan yang dihasilkan dari limbah tulang sotong mempunyai kandungan air yang bervariasi antara 1,03- 
9,98\%. Nilai ini masih termasuk dalam standard kitosan. Waktu deasetilasi tidak mempengaruhi kadar air kitosan, dapat dilihat dengan tidak beraturannya grafik yang didapat.

\subsection{Pengaruh Suhu dan Waktu Deasetilasi Terhadap Kadar Abu Kitosan}

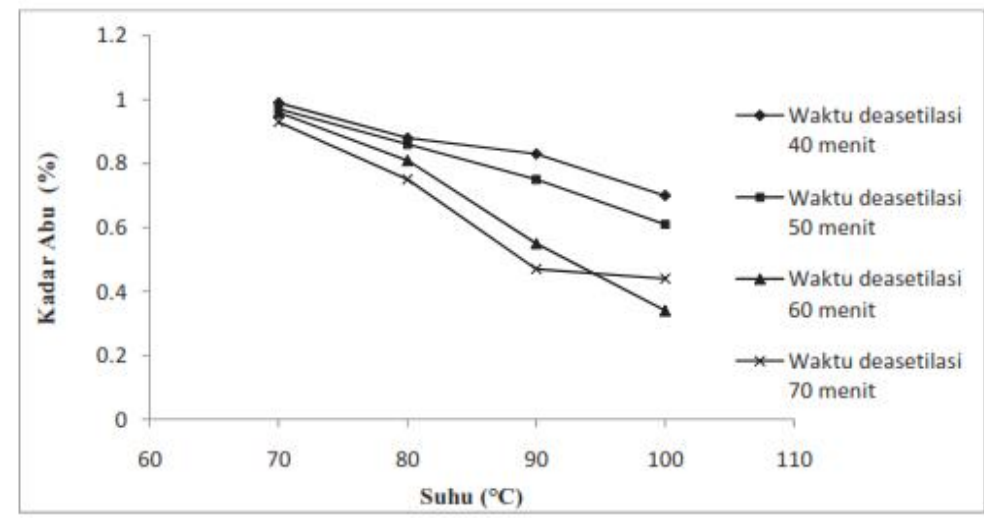

Gambar 4.2 Grafik hubungan antara suhu dan waktu deasetilasi menit terhadap

kadar abu kitosan

Kadar abu merupakan parameter untuk mengetahui mineral yang terkandung dalam suatu bahan yang mencirikan keberhasilan proses deemineralisasi yang dilakukan. Semakin rendah nilai kadar abu, maka tingkat kemurnian kitosan semakin tinggi, dan sebaliknya.

Dari gambar diatas dapat dilihat bahwa semakin tinggi suhu maka kadar abu kitosan semakin berkurang. Hal tersebut dikarenakan oleh suhu dapat membuat mineral yang terkandung dalam bahan larut dalam pelarut. Waktu deasetilasi juga mempengaruhi kadar abu kitosan. Dimana semakin lama waktu deasetilasi maka kadar abu kitosan yang didapat semakin menurun. Kadar abu yang menurun dikarenakan oleh semakin lama proses deasetilasi maka semakin banyak mineral dalam kitosan yang larut dalam larutan $\mathrm{NaOH}$. Dan semakin tinggi kadar kitosan yang digunakan maka semakin lama pula pencucian yang dilakukan untuk menetralkan $\mathrm{pH}$ kitosan. Pada saat pencucian mineral-mineral yang tidak terlarut pada proses demineralisasi ikut terbawa oleh air pencucian. Hasil analisis kadar abu dari kitosan yang dihasilkan dapat berkisar antara 0,340,99\%. Hal ini menunjukkan bahwa kitosan yang dihasilkan telah memenuhi standar mutu kadar abu kitosan yang telah diharapkan oleh Muzarelli (1985), 
dengan standard kadar abu $<1 \%$. Semakin lama waktu deasetilasi yang dilakukan menyebabkan kadar abu kitosan semakin kecil. Hal tersebut dikarenakan oleh semakin lamanya reaksi maka semakin banyak pula mineral yang terlarut pada pelaru saat proses deasetilasi.

\subsection{Pengaruh Suhu dan Waktu Deasetilasi Terhadap Viskositas Kitosan}

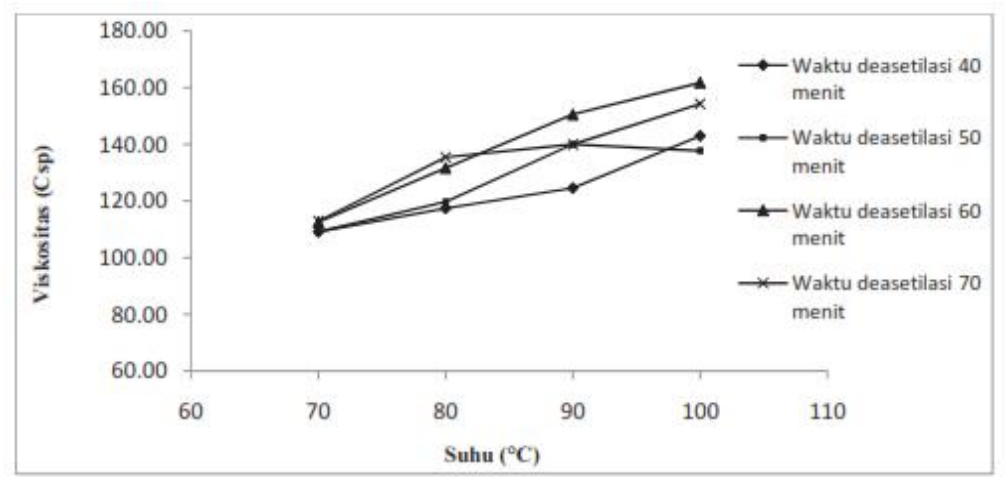

Gambar 4.3 Grafik hubungan antara suhu dan waktu deasetilasi terhadap

viskositas kitosan

Kitosan hasil preparasi dalam penelitian ini memiliki viskositas sebesar 109.11-161.78 Csp. Viskositas tertinggi pada suhu $100^{\circ} \mathrm{C}$ dengan waktu 60 menit yaitu 161,78 Csp. Nilai viskositas kitosan tersebut termasuk kategori rendah. Menurut Fernandez (1991), viskositas yang terlalu tinggi akan mempengaruhi kekentalan larutan, yang tidak diinginkan untuk penanganan industri.

Viskositas merupakan salah satu sifat karakteristik dari polimer. Larutan kitosan merupakan senyawa kimia berupa rantai-rantai polimer yang mempunyai viskositas tinggi. Informasi mengenai viskositas kitosan berhubungan dengan aplikasinya. Dalam bidang farmasi diperlukan kitosan dengan viskositas rendah, sedangkan untuk keperluan pengental atau pengeras bahan makanan diperlukan kitosan dengan viskositas tinggi (Dewi dan Fawzya, 2006).

Viskositas kitosan mengalami pengurangan seiring dengan bertambahnya waktu proses demineralisasi. Viskositas kitosan dapat diukur dengan cara melarutkan $1 \%$ kitosan ke dalam larutan asam asetat $1 \%$ kemudian diukur viskositasnya dengan alat viskometer. 
Etty Centaury Siregar dkk. / Jurnal Teknologi Kimia Unimal 5 : 2 (November 2016) 37-44

\subsection{Penentuan Gugus Fungsi Kitosan dengan Spektrofotometer FT-IR, pada Konsentrasi 50\% dan Waktu Deasetilasi 1 Jam}

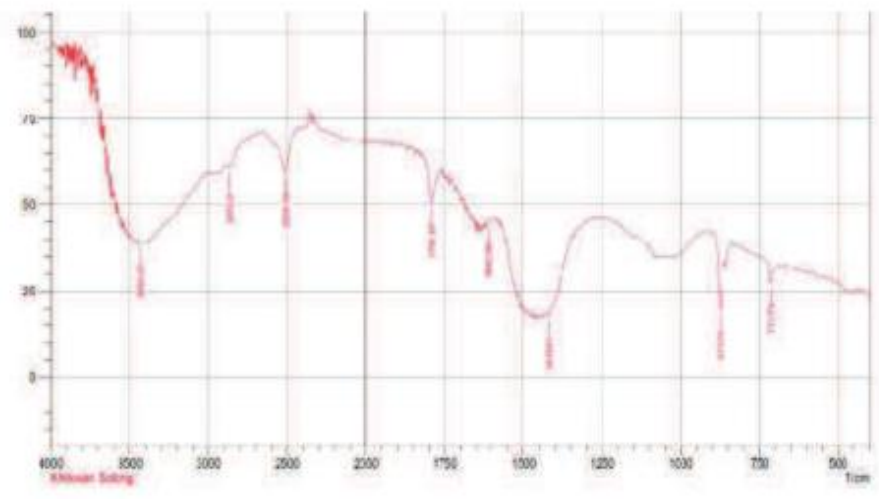

Gambar 4.4 Spektrum IR kitosan pada suhu $100^{\circ} \mathrm{C}$ dan waktu 60 menit

Pemeriksaan FT-IR untuk sampel kitosan bertujuan untuk mengetahui gugusgugus fungsi karakteristiknya dan menghitung derajat deasetilasinya. Gambar 4.4 Spektrum IR kitosan pada suhu $100^{\circ} \mathrm{C}$ dan waktu 60 menit Berdasarkan Gambar 4.5 terlihat bahwa pada spektra IR kitosan, muncul puncak serapan pada bilangan gelombang 3435,22 cm-1 menunjukkan serapan vibrasi ulur $(-\mathrm{OH})$. Menurut Fessenden (1982), suatu ikatan O-H menyerap energi pada panjang gelombang $3000-3700 \mathrm{~cm}^{-1}$. Kemunculan serapan pada bilangan gelombang $1610,56 \mathrm{~cm}^{-1}$ yang merupakan serapan vibrasi amida I (ulur $\mathrm{C}=\mathrm{O})$ juga menandakan keberadaan gugus asetil. Bilangan gelombang 1558,48 $\mathrm{cm}^{-1}$ merupakan serapan dari amida II (tekuk -NH). menunjukkan telah terjadinya proses deasetilasi yang merupakan pita serapan gugus amina pada kitosan. Berdasarkan analisis gugus fungsi di atas, ternyata pada spektra IR kitosan menunjukkan munculnya serapan-serapan karakteristik dari kitosan. Oleh karena itu, disimpulkan bahwa produk hasil preparasi pada penelitian ini adalah kitosan.

Derajat deasetilasi (DD) kitosan dari tulang sotong dalam penelitian ini mempunyai derajat deasetilasi sebesar 81,0231\%. Menurut Kusumaningsih (2004), secara umum kualitas kitosan yang digunakan mempunyai DD sebesar $60 \%$, untuk kualitas teknis sekitar $85 \%$ untuk kualitas makanan derajat deasetilasi sekitar 90\% sedangkan untuk kualitas parmasetis derajat deasetilasi sebesar 95\%. Hasil kitosan pada penelitian ini dapat digolongkan pada kualitas teknis. 
Etty Centaury Siregar dkk. / Jurnal Teknologi Kimia Unimal 5 : 2 (November 2016) 37-44

\section{KESIMPULAN}

Berdasarkan hasil penelitian ini, dapat disimpulkan bahwa kitosan dapat dibuat dari bahan baku tulang sotong dengan proses deproteinasi, demineralisasi dan deasetilasi. Suhu dan waktu deasetilasi berpengaruh pada hasil kitosan yang didapatkan. Derajat deasetilasi kitosan dari tulang sotong pada suhu $100^{\circ} \mathrm{C}$ dengan waktu 60 menit adalah 81,0231\%. Semakin tinggi suhu dan waktu deasetilasi maka viskositas kitosan semakin tinggi.

\section{DAFTAR PUSTAKA}

Alistair, M.S. 1995. Food Polysacharides and their application. Department of Chemistry, University of Capetown: Rodenbosch.

Dewi, A.S dan Fawzya, Y.N. 2006. Studi Pendahuluan: Penggunaan Berulang Larutan Natrium Hidroksida dalam Pembuatan Kitosan. Proseding Seminar Nasional Himpunan Kimia Indonesia. IPB : Bogor.

Fessenden, Ralph J dan joan S Fessenden. 1982. Kimia Organik jilid 1.Erlangga: Jakarta.

Kusumaningsih. T, 2004. Karakterisasi khitosan hasil deasetilasi kitin dari cangkang kerang hijau. Jur. Kimia FMIPA UNS.

Muzzarelli, R.A.A., 1977. Chitin. Perngam o n Press, Oxford, New York.

Muzzarelli, R.A.A., 1985. Chitin in the Polysaccharides, vol. 3, pp. 147.

Aspinall (ed) Academic press Inc., Orlando, San Diego. No.3, Madrid, Spain.

Savant, D. Vivek, and J.A. Torres. 2000. Chitosan based coagulating agents for treatment of cheddar chees whey. Biotechnology Progress 16: 1091-1097.

Suhardi. 1993. Khitin dan Khitosan, Pusat Antar Universitas Pangan\&Gizi. Universitas Gadjah Mada: Yogyakarta.

Sun,Ok; Fernandez,Kim. 2004. Physicochemical and functional roperties of crawfish chitosan as affected by different processing protocols.

Tolaimatea, A.; Desbrieresb, J.; Rhazia, M., dan Alaguic, A., 2003, Contribution to the preparation of chitins and chitosans with controlled physicochemical properties, Polym. J. , 44, 7939-7952.

Wiles, JL., Caner C, Vergano PJ., 2000. Chitosan Film Mechanical and Permeation Properties as Affected by Acid, plastizer, and Storage. Journal Food Science 63 (6):1049-1053. 